\title{
Recombinant Thyroid-Stimulating Hormone
}

National Cancer Institute

\section{Source}

National Cancer Institute. Recombinant Thyroid-Stimulating Hormone. NCI Thesaurus.

Code C887.

A recombinant form of the heterodimeric human anterior pituitary glycoprotein thyroidstimulating hormone (TSH) with potential use in hormone replacement therapy.

Recombinant TSH binds to TSH receptors on thyroid epithelial cells and stimulates TSHdependent signaling pathways. This stimulates iodine uptake and org anification, and induces synthesis and secretion of thyrog lobulin ( $\mathrm{Tg}$ ), triiodothyronine (T3), and thyroxine (T4). 